\title{
Simulated winter warming has negligible effects on germination success of Acadian Forest tree species
}

\author{
William R. Vaughn, Anthony R. Taylor, David A. MacLean, and Loïc D’Orangeville
}

\begin{abstract}
Dormant seeds that require long periods of cold stratification to become germinable may be most sensitive to increases in winter temperatures caused by anthropogenic climate change. In this study, we used outdoor plots with infrared heaters to simulate the effects of projected winter warming $\left(+6{ }^{\circ} \mathrm{C}\right)$ for Canada's Acadian Forest Region and compared seed germination success of tree species with varying stratification requirements. We evaluated four seedlots each of balsam fir (Abies balsamea (L.) Mill.), red spruce (Picea rubens Sarg.), white pine (Pinus strobus L.), red maple (Acer rubrum L.), sugar maple (Acer saccharum Marshall), and yellow birch (Betula alleghaniensis Britton). Three central findings emerged from this study: (i) none of the tested species were significantly affected by warming; (ii) the random effect of seedlot explained more variation in germination success of deciduous species than it did for conifers; and (iii) balsam fir seedlots exhibited considerable differences in their response to warming, implying intraspecific variation in depth of dormancy. These results suggest seed germination success of the tested tree species may not be impeded by their individual seed characteristics under the magnitude of winter warming projected over the coming century in our study area.
\end{abstract}

Key words: seed dormancy, climate change, winter warming, germination, stratification, Acadian Forest, balsam fir, sugar maple.

Résumé : Les graines dormantes qui ont besoin de longues périodes de stratification à froid pour germer pourraient être très sensibles à l'augmentation des températures hivernales causée par le changement climatique d'origine anthropique. Dans cette étude, nous avons eu recours à des parcelles échantillons situées à l'extérieur avec des radiateurs à infrarouge pour simuler les effets du réchauffement $\left(+6^{\circ} \mathrm{C}\right)$ hivernal anticipé dans la région de la forêt acadienne au Canada et nous avons comparé le taux de germination des graines d'espèces d'arbres dont les exigences de stratification diffèrent. Nous avons évalué quatre lots de graines dans chaque cas pour le sapin baumier (Abies balsamea (L.) Mill.), l'épicéa rouge (Picea rubens Sarg.), le pin blanc (Pinus strobus L.), l'érable rouge (Acer rubrum L.), l'érable à sucre (Acer saccharum Marshall) et le bouleau jaune (Betula alleghaniensis Britton). Trois principaux résultats découlent de cette étude : (i) le réchauffement n'a eu aucun impact significatif peu importe l'espèce testée; (ii) l'effet aléatoire des lots de graines explique plus de variation dans le taux de germination des espèces décidues que dans celui des conifères; et (iii) des différences considérables ont été observées entre les lots de graines du sapin baumier en ce qui a trait à leur réaction face au réchauffement, ce qui implique qu'il existe une variation intraspécifique de la profondeur de la dormance. Ces résultats indiquent que l'ampleur du réchauffement hivernal anticipé au cours du siècle à venir dans la zone d'étude n'est peut-être pas suffisante pour que les caractéristiques des graines des espèces d'arbres testées aient un impact sur leur taux de germination. [Traduit par la Rédaction]

Mots-clés : dormance des graines, changement climatique, réchauffement hivernal, germination, stratification, forêt acadienne, sapin baumier, érable à sucre.

\section{Introduction}

Evaluating the effects of climate change on forest stand regeneration is of increasing importance to forest managers and stakeholders. In particular, the role of winter warming on successful tree seedling establishment has been suggested as an important potential mechanism by which climate change may influence forest stand succession (Campbell et al. 2005; Kreyling 2010; Taylor et al. 2020). In the Acadian Forest Region (Rowe 1972), part of North America's boreal-temperate ecotone, many constituent tree species lie at either the northern or southern limit of their geographical range. Mean annual temperature of the Acadian Forest Region is predicted to rise by 5 to $6{ }^{\circ} \mathrm{C}$ by the end of this century under Representative Concentration Pathway 8.5 (RCP; van Vuuren et al. 2011; McKenney et al. 2013). Under the same climate change scenario, mean winter temperature is expected to increase by $6{ }^{\circ} \mathrm{C}$ (McKenney et al. 2013). This intensity of winter warming will reduce snow cover period and depth, and spring soil moisture (Houle et al. 2012), which could have significant impacts on ecological processes that control stand regeneration (Campbell et al. 2005). Specifically, the successful germination of some tree species requires a particular range of environmental

Received 19 April 2021. Accepted 7 September 2021.

W.R. Vaughn and A.R. Taylor. Canadian Forest Service - Atlantic Forestry Centre, Natural Resources Canada, 1350 Regent Street, P.O. Box 4000, Fredericton, NB E3B 5P7, Canada; Faculty of Forestry and Environmental Management, University of New Brunswick, 28 Dineen Drive, Fredericton, NB E3B 5A3, Canada.

D.A. MacLean and L. D’Orangeville. Faculty of Forestry and Environmental Management, University of New Brunswick, 28 Dineen Drive, Fredericton, NB E3B 5A3, Canada.

Corresponding author: Anthony R. Taylor (email: anthony.taylor@unb.ca).

() 2021 Authors MacLean and D’Orangeville, and The Crown. This work is licensed under a Creative Commons Attribution 4.0 International License (CC BY 4.0), which permits unrestricted use, distribution, and reproduction in any medium, provided the original author(s) and source are credited. 
conditions to relieve seed dormancy to become germinable (Walck et al. 2011). Thus, variations in these conditions may affect regeneration and establishment of these species, especially in natural stands.

The mechanisms that control seed dormancy enable a mature, viable seed to avoid germination at times when temperature and moisture conditions are not conducive to seedling survival (Baskin and Baskin 2004; Tielborger et al. 2012). Freshly matured seeds are either non-dormant (capable of germinating under favourable environmental conditions immediately after dispersal) or they possess primary dormancy due to embryonic or structural characteristics that prevent germination (Baskin and Baskin 1998, 2004; Walck et al. 2011). Physiological dormancy is a common type of embryonic dormancy (Baskin and Baskin 1998) that requires a specific combination of temperature and moisture over a period of time in order for seeds to become germinable: warm and moist conditions (warm stratification) or cool $\left(0\right.$ to $\left.10{ }^{\circ} \mathrm{C}\right)$ and moist conditions (cold stratification; Walck et al. 2011). Physiological dormancy can be categorized into deep (requires 3-4 months of cold stratification), intermediate (requires 2-3 months of cold stratification), or non-deep (requires short periods of either warm or cold stratification) (Baskin and Baskin 2004). Once seeds have been released from dormancy, they enter a quiescent state, in which they remain until exposed to specific environmental conditions that will trigger germination (Baskin and Baskin 1998; Bonner and Karrfalt 2008). Dormancy and germination are distinctly different physiological processes (Fenner and Thompson 2005); therefore, climate change may affect them independently (Walck et al. 2011).

Warmer winters could significantly lower the germination success of species that require long periods of cold stratification for their seeds to become non-dormant. For example, sugar maple (Acer saccharum Marshall), a common shade-tolerant species in the Acadian Forest Region and often found in remnant old-growth stands (Mosseler et al. 2003), requires cold stratification for 40 to 90 days (Bonner and Karrfalt 2008) at temperatures slightly above freezing to release the seeds from dormancy (Godman et al. 1990). Solarik et al. (2016) observed substantial declines (up to $75 \%$ ) in germination rates of sugar maple under moderate $\left(+5^{\circ} \mathrm{C}\right)$ and upper threshold $\left(+7^{\circ} \mathrm{C}\right)$ warming scenarios. Similarly, balsam fir (Abies balsamea (L.) Mill.) requires 28-60 days of cold stratification to break dormancy and become germinable (Bonner and Karrfalt 2008). Conversely, species that produce seeds that lack dormancy, like red spruce (Picea rubens Sarg.) (Sullivan 1993), may be unaffected by winter warming. If winter temperatures in North America continue to rise as predicted by current climate change projections, tree species that require specific environmental conditions to release their seeds from dormancy may experience reduced germination success (Solarik et al. 2016). However, should these species possess a high degree of intraspecific variation in their dormancy requirements, the range of suitable winter conditions will increase, creating a variable pattern in the individual response to winter warming (Bolnick et al. 2011).

In addition to winter temperature, snow depth plays a key role in insulating soil from cold air during winter months. A snow depth of 20-40 cm causes a decoupling of air and soil temperatures under most conditions (Sharratt et al. 1992; Zhang 2005). Consequently, winter soil temperature may decrease with less snow cover due to reduced insulation (Venäläinen et al. 2001; Decker et al. 2003). Drescher and Thomas (2013) found that germination success declined with decreasing snow depth for balsam fir, red maple (Acer rubrum L.), and sugar maple seeds due to exposure to cold temperatures, while germination success of white pine (Pinus strobus L.) showed no significant change. Variations in snow regime will have other effects, including an increased frequency of freeze-thaw cycles of the upper soil layers (Decker et al. 2003; Mellander et al. 2007). This could cause some seeds to germinate early (if cold stratification requirement has already been satisfied) during a period of warm weather and subsequently die once cold temperatures resume (Walck et al. 2011).

In this study, we conducted an outdoor experiment to test the effects of projected winter warming on the germination success of balsam fir, red spruce, white pine, red maple, sugar maple, and yellow birch (Betula alleghaniensis Britton), all commercially and ecologically important tree species in the Acadian Forest Region that vary in their level of seed dormancy. We hypothesized that (i) germination success of seeds that require long durations of cold stratification (balsam fir, white pine, red maple, and sugar maple) will decrease with warming due to insufficient stratification period length; and (ii) seeds of species that lack dormancy or require only short periods of cold stratification (red spruce and yellow birch) will not be affected by warming because the conditions of warmer winters will remain sufficient for their release from dormancy and (or) seed imbibition.

\section{Methods}

\section{Experimental design}

Our study was located at the Canadian Forest Service's Atlantic Forestry Centre in Fredericton, New Brunswick, which is located approximately in the middle of the Acadian Forest Region $\left(45.96^{\circ} \mathrm{N}\right.$, $66.64^{\circ} \mathrm{W}$ ). Eight outdoor seedbeds were constructed in an open space adjacent to the Atlantic Forestry Centre greenhouse to compare seed germination success between current and projected Fredericton winter climate conditions under the high emissions RCP 8.5 radiative forcing scenario. Winter climate projections were obtained from high-resolution interpolated climate data provided by Natural Resources Canada (McKenney et al. 2013) for Fredericton for the period of 2071-2100. Unless further mitigation efforts are initiated to reduce greenhouse gas emissions beyond those currently in place, the RCP 8.5 high emissions scenario is increasingly likely (Pachauri et al. 2014, Foster et al. 2017; United Nations Environment Programme 2019; Voosen 2019). Mean annual temperature in Fredericton is $5.6^{\circ} \mathrm{C}$, and mean January and July temperatures are $-9.4{ }^{\circ} \mathrm{C}$ and $19.3^{\circ} \mathrm{C}$, respectively (climate normal data for the period of 1981-2010; Environment Canada 2019). Mean annual snowfall is $252 \mathrm{~cm}$, and the average annual frost-free period is 130 days (climate normal data for the period of 1981-2010; Environment Canada 2019).

Two treatment factors were tested in a fully crossed design: temperature (control and heated) and species (balsam fir, red spruce, white pine, red maple, sugar maple, and yellow birch). Temperature in the heated treatment was manipulated with infrared heaters to mimic the projected $6{ }^{\circ} \mathrm{C}$ increase in mean winter temperature under RCP 8.5 for the Acadian Forest Region (relative to 1981-2020 normals; McKenney et al. 2013), and the control treatment had no additional warming. The experiment had four replicate plots each of the control and heated treatments and ran from 17 December 2019 to 15 April 2020. Stratification requirements vary among the tested species with balsam fir, white pine, red maple, and sugar maple seeds all expressing intermediate physiological dormancy, while yellow birch seeds express non-deep physiological dormancy and red spruce seeds are non-dormant (Bonner and Karrfalt 2008). To test for intraspecific variation and add genetic diversity, four seedlots (one parent tree per seedlot) of each of the six tree species were selected for the experiment, with all seedlot locations occurring in natural stands within $75 \mathrm{~km}$ of the city of Fredericton to minimize variation in seedlot origin climate.

\section{Seed source and preparation}

Tree seeds from Canada's National Tree Seed Centre were used for the experiment (National Tree Seed Centre 2020). Seeds at the National Tree Seed Centre are collected at maturity by experienced seed collectors, dried to $5 \%-7 \%$ moisture and stored at $-20^{\circ} \mathrm{C}$. 
Fig. 1. Seed plot layout and design: (a) arrangement of the 24 seed bags within one seedbed and locations of the soil temperature and moisture sensors; $(b)$ the seedbed after the seed bags were covered with peat moss; $(c)$ the entire site where the eight plots were set up in two rows of four (the closest plot was not used) and the location of one of the ambient air temperature sensors; and (d) location of the seedbed relative to the infrared heater and infrared temperature sensor.
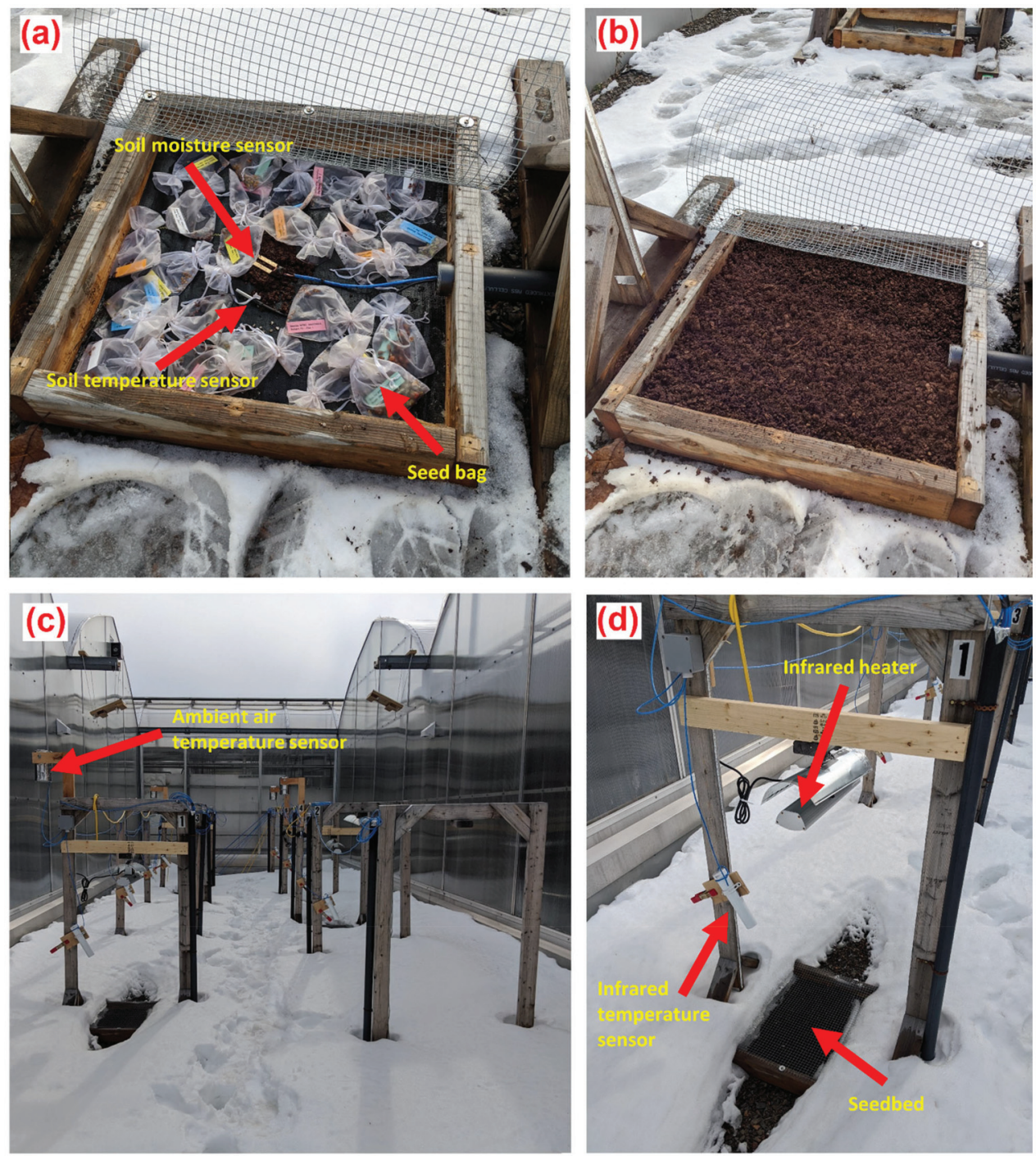

Dormant seeds require a specific combination of temperature and moisture to be released from dormancy; therefore, due to the sub-zero temperature in which seeds at the National Tree Seed Centre are stored and their low moisture content, depth of dormancy is not affected (Walck et al. 2011). Additionally, both Liu and El-Kassaby (2015) and Solarik et al. (2016) found that seed dormancy did not diminish in cold storage, so for the purpose of this study, seeds from the National Tree Seed Centre were considered suitable. Two hundred seeds (four seedlots $\times 50$ seeds) of each of the six species were placed in all replicate plots of each treatment. The 50 seeds of each seedlot were counted and placed in mesh bags, which were then randomly distributed into seedbeds measuring $60 \mathrm{~cm}$ wide $\times 60 \mathrm{~cm}$ long $\times 9 \mathrm{~cm}$ deep and buried in peat moss (representing the leaf litter layer; Figs. 1a, 1b). Wire mesh covered the top and bottom of the seedbeds to prevent rodent predation and allow for drainage. The results of previous, standardized germination tests conducted by the National Tree Seed Centre for the selected seedlots are displayed in Table 1. These germination rates ranged from $51.5 \%$ to $67.5 \%$ (balsam fir), $72.0 \%$ to $98.5 \%$ (red spruce), $90.0 \%$ to $100 \%$ (white pine), $74.0 \%$ to
$96.0 \%$ (red maple), $56.0 \%$ to $65.0 \%$ (sugar maple), and $60.5 \%$ to 91.0\% (yellow birch).

\section{Plot design}

The eight seedbeds were randomly placed in two rows of four plots next to the Atlantic Forestry Centre greenhouse (Fig. 1c). Each plot consisted of a $60 \mathrm{~cm} \times 60 \mathrm{~cm}$ seedbed placed on the ground under a $150-\mathrm{cm}$-tall wooden stand that was used to mount the infrared heaters (heated plots only) and infrared temperature sensors (Fig. 1d). The infrared temperature sensors (MLX90614ESFBCF-000-SP, Melexis, Ypres, Belgium) were mounted on the side of each stand, and ambient air temperature sensors (SEN0227, DFRobot, Shanghai, P.R. China) were mounted $180 \mathrm{~cm}$ above the ground on each heated plot stand (Fig. 1c). Seedbed temperature and moisture were measured throughout the experiment with soil temperature sensors (DS18B20, DFRobot, Shanghai, P.R. China) and moisture sensors (SEN-13637, Sparkfun Electronics, Niwot, Colorado, USA) that were located under the peat moss among the seed bags (Fig. 1a). Seedbed moisture was measured throughout the experiment to ensure adequate levels were maintained for seed imbibition. 
Table 1. National Tree Seed Centre laboratory germination rates and the observed germination rates following control and heated treatments.

\begin{tabular}{|c|c|c|c|c|c|c|}
\hline \multirow[b]{3}{*}{ Species } & \multirow[b]{3}{*}{ Seedlot } & \multirow{3}{*}{$\begin{array}{l}\text { Laboratory } \\
\text { germination } \\
\text { rate }(\%)\end{array}$} & \multicolumn{4}{|c|}{ Treatment germination rates (\%) } \\
\hline & & & \multicolumn{2}{|l|}{ Control } & \multicolumn{2}{|l|}{ Heated } \\
\hline & & & Seedlot & Species & Seedlot & Species \\
\hline \multirow[t]{4}{*}{ Abies balsamea } & 20021325 & 51.5 & 34.5 & 35.4 & 47.5 & 25.4 \\
\hline & 20021327 & 66.5 & 30.0 & & 14.5 & \\
\hline & 20021331 & 67.5 & 30.5 & & 3.5 & \\
\hline & 20021332 & 61.0 & 46.5 & & 36.0 & \\
\hline \multirow[t]{4}{*}{ Picea rubens } & 9610241 & 88.5 & 88.5 & 86.6 & 80.5 & 85.3 \\
\hline & 9810257 & 72.0 & 74.5 & & 91.5 & \\
\hline & 9810269 & 76.0 & 85.0 & & 79.0 & \\
\hline & 20001207 & 98.5 & 98.5 & & 90.0 & \\
\hline \multirow[t]{4}{*}{ Pinus strobus } & 20001173 & 90.0 & 95.5 & 96.0 & 96.5 & 92.3 \\
\hline & 20001176 & 95.5 & 95.0 & & 82.0 & \\
\hline & 20001177 & 100.0 & 98.0 & & 99.0 & \\
\hline & 20001178 & 100.0 & 95.5 & & 91.5 & \\
\hline \multirow[t]{4}{*}{ Acer rubrum } & 20021025 & 91.0 & 43.5 & 53.6 & 38.0 & 53.4 \\
\hline & 20021026 & 80.0 & 28.5 & & 26.0 & \\
\hline & 20021064 & 74.0 & 70.5 & & 75.5 & \\
\hline & 20021067 & 96.0 & 72.0 & & 74.0 & \\
\hline \multirow[t]{4}{*}{ Acer saccharum } & 20021132 & 62.0 & 54.0 & 55.1 & 50.5 & 49.0 \\
\hline & 20021136 & 56.0 & 49.0 & & 38.5 & \\
\hline & 20021144 & 57.0 & 41.5 & & 33.0 & \\
\hline & 20081147 & 65.0 & 76.0 & & 74.0 & \\
\hline \multirow[t]{4}{*}{ Betula alleghaniensis } & 20001104 & 60.5 & 71.0 & 78.5 & 69.0 & 77.8 \\
\hline & 20021103 & 80.5 & 77.5 & & 74.5 & \\
\hline & 20021124 & 91.0 & 80.5 & & 79.5 & \\
\hline & 20021125 & 82.5 & 85.0 & & 88.0 & \\
\hline
\end{tabular}

Snow was allowed to accumulate during the experiment and the depth at the middle of the seedbed was measured throughout the experiment with a measuring tape installed on the side of each stand.

\section{Temperature manipulation}

The heated treatment either maintained a $6{ }^{\circ} \mathrm{C}$ difference between control and heated plot surface temperatures with a $0{ }^{\circ} \mathrm{C}$ upper limit or maintained a constant $6.0^{\circ} \mathrm{C}$ difference between treatments with no limit. In a natural forest setting, depth of leaf litter and snow accumulation may act to decouple seedbed and ambient air temperatures. To allow for this potential thermal decoupling in our experiment due to snow accumulation, leaf litter (simulated with peat moss) or both, we chose to only apply warming to the plot surface in the heated treatment and allow seedbed temperatures to vary accordingly. The temperature in each of the heated plots was maintained by an infrared heater that was cycled on and off with a relay. The relay was controlled by an Adafruit Feather Huzzah ESP 8266 microcontroller (Adafruit, New York, New York, USA), which measured the temperature difference between the heated plot surface temperature and the ambient air temperature every $4 \mathrm{~s}$. Ambient air temperature was used as an estimate of control plot surface temperature, as it was observed to be $\pm 1^{\circ} \mathrm{C}$ of the actual surface temperature and was less sensitive to fluctuations in solar radiation.

The physical properties of snow posed a challenge when attempting to warm plot surfaces to temperatures above $0^{\circ} \mathrm{C}$. For example, if the air temperature was $-3^{\circ} \mathrm{C}$, the heated plot infrared lamps would attempt to warm the plot surface to $+3^{\circ} \mathrm{C}$; however, if the plot was covered with snow, which has a maximum temperature of $0{ }^{\circ} \mathrm{C}$, the target temperature would not be reached until the snow melted enough to expose the seedbed. To prevent an unnatural rate of snowmelt during the coldest winter months, the microcontrollers were programmed to warm the heated plots to a maximum of $0{ }^{\circ} \mathrm{C}$ from 17 December to 15 March. Climate data from Natural Resources Canada for the years 20712100 under RCP 8.5 indicates average winter low temperature during this period will be below $0{ }^{\circ} \mathrm{C}$ (McKenney et al. 2013), so we assumed that significant, prolonged snowmelt should not frequently occur during this time. After 15 March, the microcontrollers were programmed to maintain a constant $6^{\circ} \mathrm{C}$ difference between the control and heated plots with no restrictions. This was done to mimic an early spring onset, which is predicted to occur under the RCP 8.5 scenario (McKenney et al. 2013; Bush and Lemmen 2019).

\section{Seed germination}

The seed bags were extracted from all plots on 15 April when the plot areas were completely free of snow cover. The seeds were then removed from the seed bags and thoroughly rinsed with water. At this point, any seeds that had germinated during the stratification experiment were counted. Radical protrusion through the seed coat was used as the indicator of successful germination (Baskin and Baskin 2004). The remaining seeds from each plot were then divided by species and placed in germination trays (six trays per plot) on Kimpacks moistened with $125 \mathrm{~mL}$ of distilled water. Each tray bottom received an additional $125 \mathrm{~mL}$ of 
Fig. 2. Winter temperature variation between ambient air temperature and (a) surface temperature of control and heated plots, and (b) seedbed temperature of control and heated plots. Technical difficulties with the network resulted in missing data on the following dates: 28 December to 6 January, 8 January, and 24-26 January. Red dotted line indicates the end of the programmed $0{ }^{\circ} \mathrm{C}$ temperature limit.

Plot Surface Temperature vs. Ambient Air Temperature
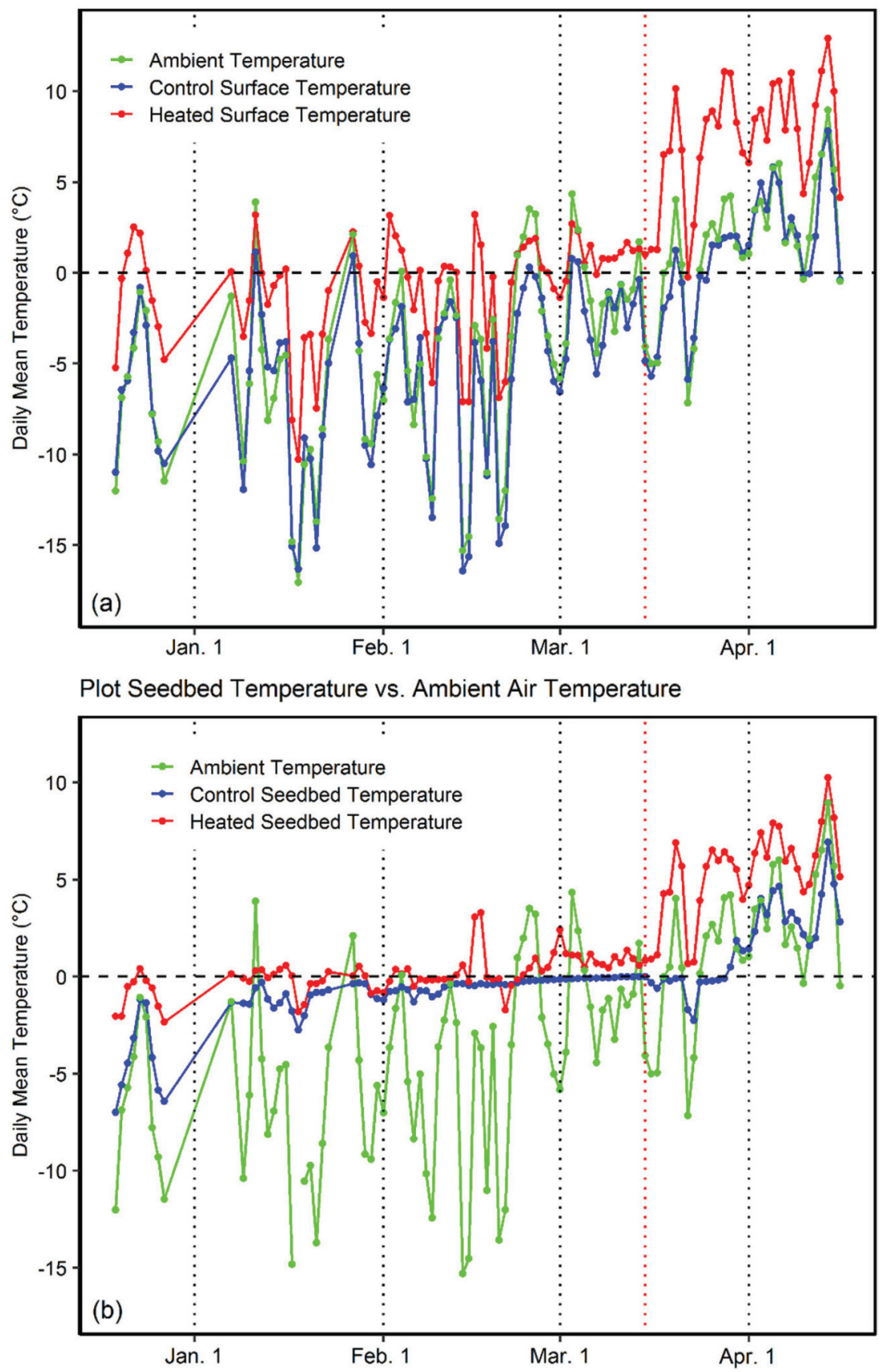

distilled water to maintain high humidity. The filled trays were loaded into a germinator that maintained a temperature schedule of $20^{\circ} \mathrm{C}$ for $16 \mathrm{~h}$ and $30^{\circ} \mathrm{C}$ for $8 \mathrm{~h}$ over a period of 28 days as per the standard protocol outlined in Bonner and Karrfalt (2008). Because we were only interested in the effect of warming on seed dormancy, we applied a standardized seed germination temperature schedule (Bonner and Karrfalt 2008). The germinator consisted of a wood frame equipped with eight open shelves and covered with thin, translucent poly plastic. Temperature was maintained with a space heater controlled by an ITC-308 temperature controller (Inkbird, Shenzhen, P.R. China) and the air was constantly circulated with a fan. Each shelf contained all six trays of one plot, and trays were rotated every 2 days. Germinants were counted every 2-4 days for the first 2 weeks and once every 7 days for the last 2 weeks.

\section{Statistical analysis}

To test our hypotheses regarding the effects of winter warming projected under RCP 8.5 on germination success, mixed effects analysis of variance (ANOVA) was conducted using the "lme4" package (Bates et al. 2017) of R (R Core Team 2020). Although tree species was found to be a highly significant factor, we instead chose to conduct separate, species-specific ANOVA models to help simplify interpretation using the following model structure: 


$$
Y=\beta_{0}+\beta_{1} T+\pi_{\text {plot }}+\pi_{\text {seedlot }}+\varepsilon
$$

where $Y$ is the proportion of germinated seeds per seed bag, $T$ is the treatment (control or heated), $\pi_{\text {plot }}$ is the random effect of plot, $\pi_{\text {seedlot }}$ is the random effect of seedlot, and $\varepsilon$ is random error. All germination proportions were arcsine square-root transformed to stabilize variance (Sokal and Rohlf 1995). For our chosen sample size $(n=200)$, alpha level $(0.05)$, and power $(0.8)$, we determined the detectable effect size to be a $7.6 \%$ difference in percent germination using the "pwr" package (Champely 2020). The "AICcmodavg" package (Mazerolle 2020) was used to calculate the small-samplecorrected Akaike's Information Criterion (AICc) of models with the random effect of plot, and models with the additional random effect of seedlot, using the restricted maximum likelihood estimation procedure. Marginal and conditional $R^{2}$ values were also calculated for each model using the "MuMIn" package (Barton 2020) to further evaluate model fit and the contribution of the random effect factors using the methods of Nakagawa and Schielzeth (2013). The marginal $R^{2}$ estimates the variation explained by the fixed effects only, while conditional $R^{2}$ includes the additional variation contributed by the random effects, which approximates the conventional $R^{2}$. Heteroscedasticity and normality of model residuals were visually assessed by inspecting the model residuals versus fitted values and Normal Q-Q plots using the "ggResidPanel" package (Goode and Rey 2019), and statistically analyzed with the Shapiro-Wilk test for normality.

\section{Results}

\section{Site environmental conditions}

The heated treatment resulted in plot surface and seedbed temperature differences between the control and heated plots (Figs. 2a, 2b). Between 17 December and 15 April, mean ambient air temperature was $-3.4 \pm 6.4^{\circ} \mathrm{C}$. Mean control and heated surface temperatures were $-3.7 \pm 6.0$ and $1.6 \pm 5.9^{\circ} \mathrm{C}$, respectively, representing a $5.3^{\circ} \mathrm{C}$ difference between treatments means. In comparison, the average difference between seedbed temperatures of the control $\left(-0.4 \pm 2.5^{\circ} \mathrm{C}\right)$ and heated $\left(1.6 \pm 3.3^{\circ} \mathrm{C}\right)$ plots was only $2.0^{\circ} \mathrm{C}$. Mean number of chilling days (accumulated time when seedbed temperature was between -1 and $5{ }^{\circ} \mathrm{C}$ ) for the control and heated plots were 76.7 and 63.3 days, respectively. While the heated treatment was programmed to limit warming to a maximum of $0{ }^{\circ} \mathrm{C}$ between 17 December and 15 March, additional warming from the sun during clear days caused the surface temperatures of the heated plots to rise above $0^{\circ} \mathrm{C}$ several times, while surface temperatures of the control plots remained at or below $0^{\circ} \mathrm{C}$ due to the high albedo of snow (Fig. $2 a$ ). The daily mean ambient air temperature, which fluctuated between -17.1 and $9.0^{\circ} \mathrm{C}$, closely tracked the daily mean surface temperature of the control plots (Fig. 2a). Daily mean surface temperatures of control and heated plots ranged from -16.4 to $7.8^{\circ} \mathrm{C}$ and -10.3 to $12.9^{\circ} \mathrm{C}$, respectively, and daily mean seedbed temperatures ranged from -7.0 to $6.9^{\circ} \mathrm{C}$ and -2.3 to $10.3^{\circ} \mathrm{C}$, respectively. Therefore, there were clear differences in both the surface and seedbed temperatures between the two treatments.

In the winter of 2019-2020, mean monthly temperatures for December, January, February, March, and April were -4.1, -6.9, $-7.5,-1.6$, and $3.5^{\circ} \mathrm{C}$, respectively (data acquired from the Fredericton International Airport weather station located in Lincoln, New Brunswick, Canada, at $45.87^{\circ} \mathrm{N}$ and $66.54^{\circ} \mathrm{W}$ ). Historical mean monthly temperatures (2012-2019 data from the Fredericton International Airport weather station) were $-5.0^{\circ} \mathrm{C}(-8.6$ to $\left.-0.8^{\circ} \mathrm{C}\right),-8.6^{\circ} \mathrm{C}\left(-11.3\right.$ to $\left.-6.5^{\circ} \mathrm{C}\right),-8.1^{\circ} \mathrm{C}\left(-14.7\right.$ to $\left.-5.2^{\circ} \mathrm{C}\right),-2.6^{\circ} \mathrm{C}$ (-6.3 to $\left.0.5^{\circ} \mathrm{C}\right)$, and $4.2^{\circ} \mathrm{C}\left(2.4\right.$ to $\left.6.0^{\circ} \mathrm{C}\right)$ for December, January, February, March, and April. Although monthly mean temperatures during the experiment were slightly warmer than the historical monthly means, they fell within the monthly mean temperature ranges.
Fig. 3. Mean $( \pm 1 \mathrm{SE})$ snow depth of control and heated plots. Dashed and dotted lines indicate the 1st and 15th of each month, respectively. Measurements ceased after 9 March 2020 due to COVID-19 lockdown.

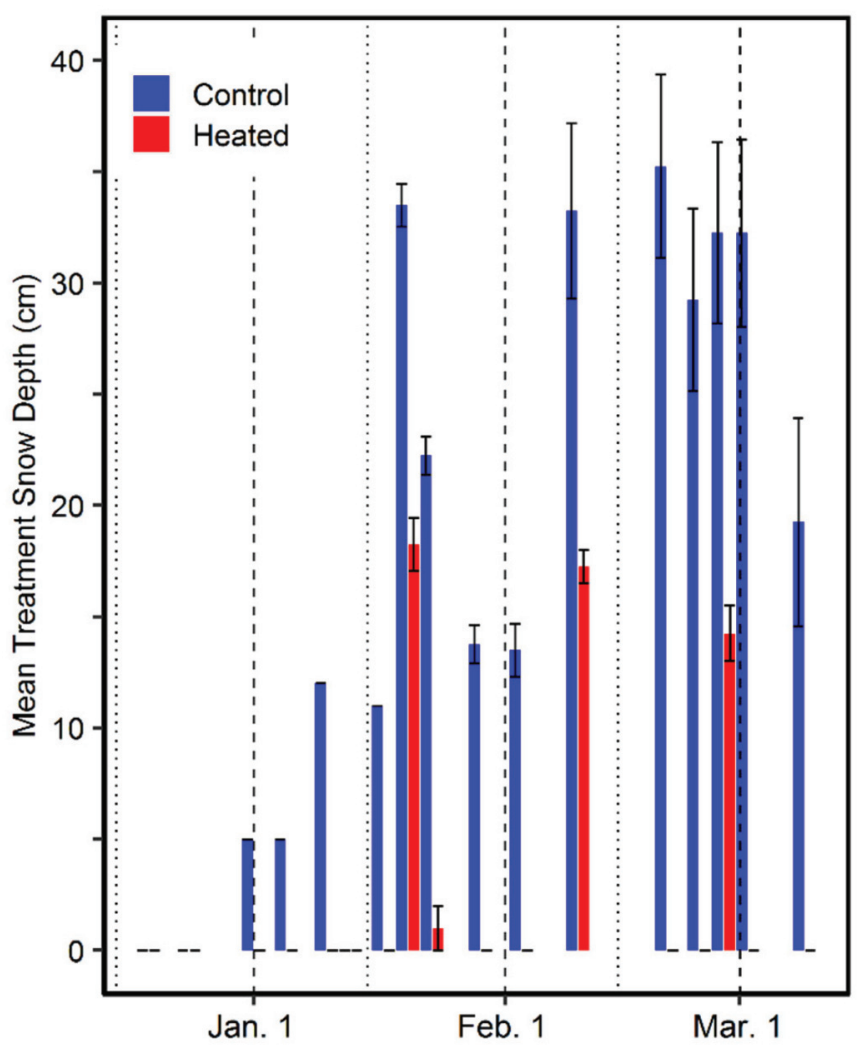

Over the course of the experiment, snow depths of the heated and control plots ranged from 0.0 to $18.3 \mathrm{~cm}$ (mean $=3.0 \mathrm{~cm})$ and 0.0 to $35.3 \mathrm{~cm}$ (mean $=17.5 \mathrm{~cm}$ ), respectively (Fig. 3). Due to significantly less snow accumulation and a higher frequency of snowmelt events in the heated plots, heated plot daily mean seedbed temperature experienced greater fluctuations and more frequent freeze-thaw cycles than control plots, especially from early February to late March (Fig. 2b). During this period, control plot snow depth was approximately $15 \mathrm{~cm}$ or greater (Fig. 3) and the control daily mean maximum seedbed temperature remained at or below $0{ }^{\circ} \mathrm{C}$ (Fig. $4 a$ ). In contrast, over the same period, the daily mean maximum seedbed temperature of the heated treatment was frequently above $0{ }^{\circ} \mathrm{C}$ (Fig. 4a). However, there were only 8 days between 17 December and 15 March that recorded maximum daily mean seedbed temperatures greater than $5^{\circ} \mathrm{C}$ for the heated plots. Data collected from the seedbed moisture sensors indicated that all seedbeds in both treatments were above $50 \%$ soil moisture for the duration of the experiment.

\section{Winter warming treatment effect and model comparison}

Overall, warming had no significant effect on the seed germination success of the tested tree species (Table 2; Fig. 5). Interestingly, some balsam fir seedlots displayed strong responses to the warming treatment: one of the balsam fir seedlots exhibited an $88.5 \%$ reduction in mean germination success while another seedlot increased by $37.7 \%$ (Table 1; Fig. 6b). Similar inconsistencies in the response to warming were also observed in seedlots of other species; however, none were as large. Interestingly, yellow birch seedlots exhibited very little change (no more than 5\%) in germination success under warming.

Under the control treatments, $97.1 \%$ and $76.5 \%$ of the total germinated sugar maple and red maple seeds, respectively, had 
Fig. 4. Daily mean treatment maximum $(a)$ and minimum $(b)$ seedbed temperatures of control and heated plots. Technical difficulties with the network resulted in missing data on the following dates: 28 December to 6 January, 8 January, and 24-26 January. Red dotted line indicates the end of the programmed $0{ }^{\circ} \mathrm{C}$ temperature limit.
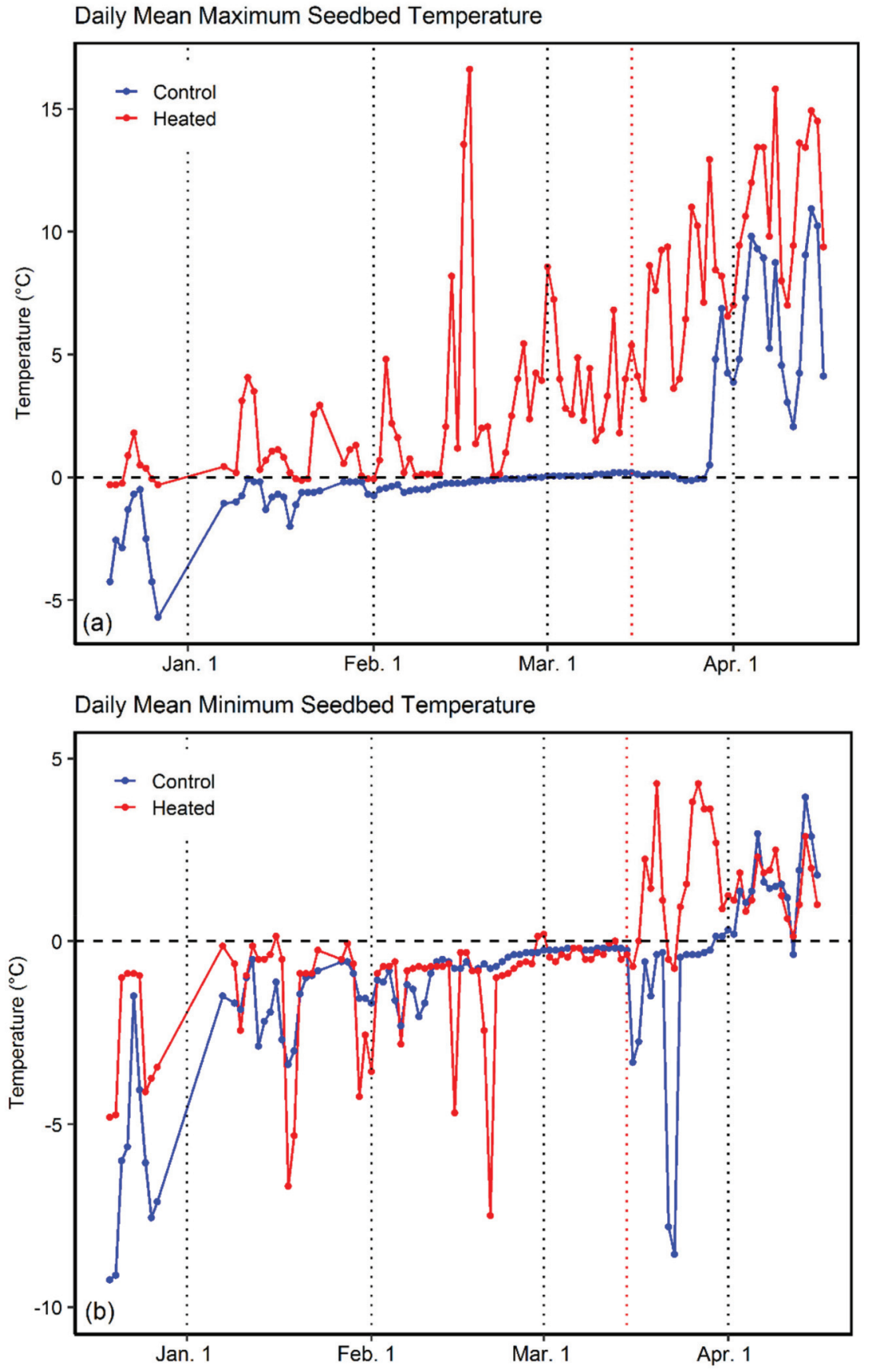

Table 2. Effect of heated treatment on seed germination rate of balsam fir, red spruce, white pine, red maple, sugar maple, and yellow birch $(\alpha \leq 0.05)$.

\begin{tabular}{lll}
\hline Species & F value & $P$ value \\
\hline Balsam fir & 1.329 & 0.29 \\
Red spruce & 0.003 & 0.96 \\
White pine & 0.367 & 0.57 \\
Red maple & 0.024 & 0.88 \\
Sugar maple & 0.455 & 0.53 \\
Yellow birch & 0.003 & 0.95 \\
\hline
\end{tabular}

germinated prior to removing the seed bags from the plots on 15 April. For the heated treatments, these values increased to $\mathbf{9 9 . 0 \%}$ and $\mathbf{8 8 . 8 \%}$ for sugar maple and red maple, respectively. Many of the sugar maple seedlings that germinated early had completely emerged from the seed coats with fully developed cotyledons. No other species had germinated prior to removing the seed bags from the control plots; however, under warming, all other species exhibited some germination prior to removing the seed bags from the plots, but no more than $10 \%$ of the total germinated seeds.

The model that provided the best fit for germination success differed between coniferous and deciduous species. For coniferous 
Fig. 5. Mean ( $\pm 1 \mathrm{SE})$ germination results for six species (BF, balsam fir; RS, red spruce; WP, white pine; RM, red maple; SM, sugar maple; $\mathrm{YB}$, yellow birch) in control and heated plots. Each bar represents four replicate plots containing four seed bags (50 seeds per bag from one of four seedlots) totaling 800 seeds.

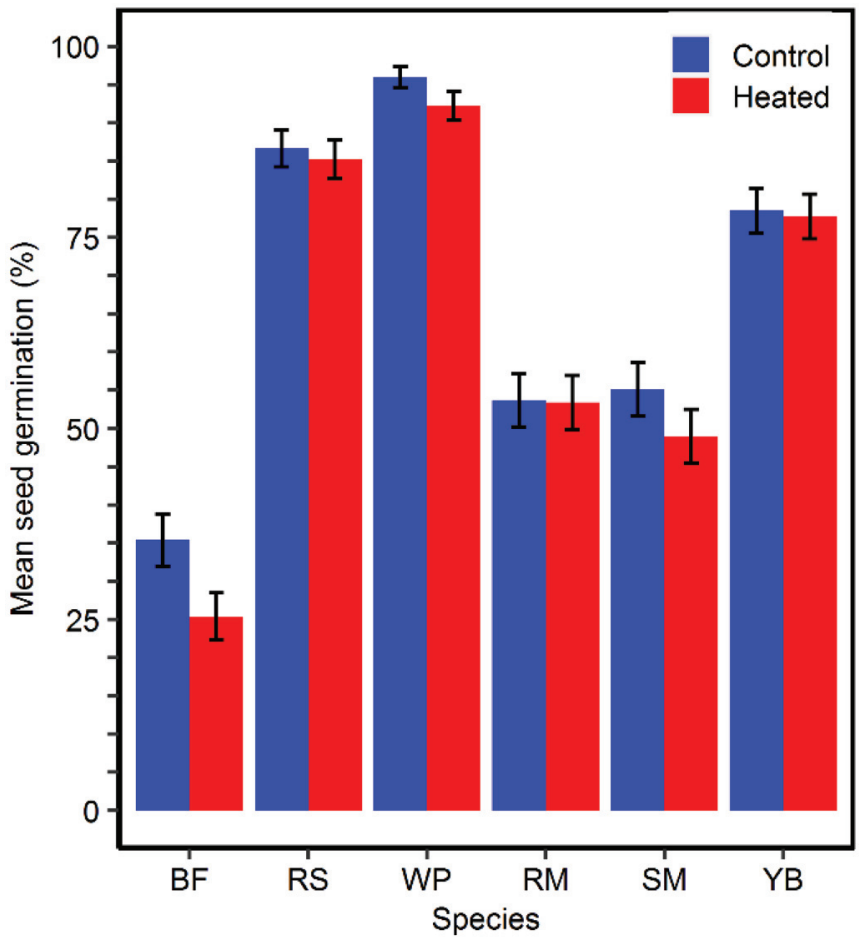

balsam fir, red spruce, and white pine, the models that contained the single random effect of plot produced the lowest AICc values (Table 3). Conversely, for deciduous red maple, sugar maple, and yellow birch, the models that contained the additional random effect of seedlot produced the lowest AICc values (Table 3). Furthermore, models for deciduous species that contained both random effects produced much larger conditional $R^{2}$ values than models with the single random effect of plot, while the conditional $R^{2}$ values of models for coniferous species exhibited minimal change with the additional random effect (Table 3). This suggests that seedlot accounted for much more of the variation in germination rates for red maple, sugar maple, and yellow birch than it did for balsam fir, red spruce, and white pine. This is clearly shown in Fig. 6, with deciduous species exhibiting considerable variation in seedlot germination rates in both treatments, while coniferous species produced minimal variation in both the control and heated treatments (except balsam fir).

\section{Discussion}

The results of our study do not support our first hypothesis that germination success of seeds that require long durations of cold stratification (i.e., balsam fir, white pine, red maple, and sugar maple) will decrease with warming, but rather suggest the magnitude of winter warming projected for the Acadian Forest Region under RCP 8.5 may not affect germination success. Although we applied a $6{ }^{\circ} \mathrm{C}$ warming treatment, the heated plots maintained average seedbed temperatures between -1 and $5{ }^{\circ} \mathrm{C}$ for a total of 63.3 chilling days, which studies have shown to be adequate for breaking dormancy in seeds that exhibit intermediate physiological dormancy (Bonner and Karrfalt 2008; Solarik et al. 2016). Additionally, the seedbed moisture content that was observed (approximately 50\% or greater) in this experiment was sufficient,
Table 3. Comparisons between species' models with the random effect of plot $\left(\pi_{\text {plot }}\right)$ and models with the additional random effect of seedlot $\left(\pi_{\text {seedlot }}\right)$.

\begin{tabular}{|c|c|c|c|c|c|c|}
\hline \multirow[b]{2}{*}{ Species } & \multicolumn{3}{|c|}{$\underline{T+\pi_{\text {plot }}}$} & \multicolumn{3}{|c|}{$\underline{T+\pi_{\text {plot }}+\pi_{\text {seedlot }}}$} \\
\hline & $\triangle \mathrm{AICc}$ & $R_{\mathrm{M}}^{2}$ & $R_{\mathrm{C}}^{2}$ & $\triangle \mathrm{AICc}$ & $R_{\mathrm{M}}^{2}$ & $R_{\mathrm{C}}^{2}$ \\
\hline Balsam fir & $\mathbf{0}^{*}$ & 0.04 & 0.06 & 2.33 & 0.04 & 0.16 \\
\hline Red spruce & $\mathbf{0}^{*}$ & 0.00 & 0.12 & 3.30 & 0.00 & 0.14 \\
\hline White pine & 0* & 0.02 & 0.13 & 1.17 & 0.01 & 0.31 \\
\hline Red maple & 9.65 & 0.00 & 0.00 & 0* & 0.00 & 0.60 \\
\hline Sugar maple & 16.81 & 0.02 & 0.19 & 0* & 0.02 & 0.78 \\
\hline Yellow birch & 3.96 & 0.00 & 0.00 & 0* & 0.00 & 0.38 \\
\hline
\end{tabular}

Note: Small-sample-corrected Akaike's Information Criterion (AICc) was used to determine whether model fit significantly improved with the addition of the random effect of seedlot. The difference in criterion value with the best-fit model is shown with $\triangle \mathrm{AICc}\left(\mathbf{0}^{*}\right.$ represents best-fit model). Marginal and conditional $R^{2}$ values were calculated to quantify the variation explained by the fixed effect of treatment $(T)$ and the additional variation accounted for by the random effects ( $\pi_{\text {plot }}$ and $\left.\pi_{\text {seedlot }}\right)$, respectively.

as past literature has found that stratification substrate moisture content of $24 \%$ or greater to be adequate for breaking physiological dormancy (Luo et al. 2020). Therefore, because seedbed temperature and moisture of the heated plots were within suitable ranges for stratification, a significant reduction in the germination success of the tested species with intermediate dormancy was not likely to occur. Moreover, when comparing the winter of 2019-2020 to the historical climate data, it was slightly warmer than the historical trend, which, presumably, should have increased the likelihood of observing a significant effect due to warming. The tested tree species that produce seeds that are either non-dormant or lack lengthy cold stratification requirements (red spruce and yellow birch) were unaffected by the warming treatment, which supports our second hypothesis.

Results of our study differ from several past field studies that examined the effects of future reductions in snow depth (due to winter warming) on seed germination success. Drescher and Thomas (2013) performed a snow removal experiment and found germination success of balsam fir, red maple, and sugar maple was significantly reduced when snow accumulation was restricted. In their experiment, the temperature that the seeds experienced in the snow-free plots closely tracked ambient air temperature, as no warming treatment was applied. Similarly, Milbau et al. (2009) tested the effects of reduced snow depth on the germination success of subarctic tundra species by exposing them to a "thin snow cover" stratification treatment. This treatment simulated real soil temperature data that was recorded in wind-swept subarctic plots with thin snow cover, and they found that germination success of some herbaceous and shrub species was reduced under the "thin snow cover" treatment. Although we did not remove snow from the plots, the heated plots had significantly less snow accumulation than the controls (Fig. 3); however, no treatment effect was observed. Unlike past snow manipulation experiments, our experiment simulated future winter warming by heating plot surfaces with infrared heat. This prevented the seedbed temperature of the heated plots from closely tracking current ambient air temperature when snow was absent and resulted in warmer seed stratification temperatures than those observed by other studies. Previous winter warming studies that attempt to determine the effect of reduced snow depths do not generally account for concurrent increases in ambient air temperature with climate change, which may increase the likelihood of observing a treatment effect due to low stratification temperatures. Drescher and Thomas (2013) and Milbau et al. (2009) applied stratification temperatures that were equal to or less than $-5{ }^{\circ} \mathrm{C}$ - well below the effective temperature range for relieving physiological dormancy in seeds (Seeley 1997; Bonner and Karrfalt 2008) and much colder 
Fig. 6. Mean ( $\pm 1 \mathrm{SE}$ ) germination results for four seedlots (different colors) of six species (BF, balsam fir; RS, red spruce; WP, white pine; RM, red maple; SM, sugar maple; YB, yellow birch) in control and heated plots. Each bar represents four replicate plots, with each plot containing 50 seeds of one seedlot, totaling 200 seeds.

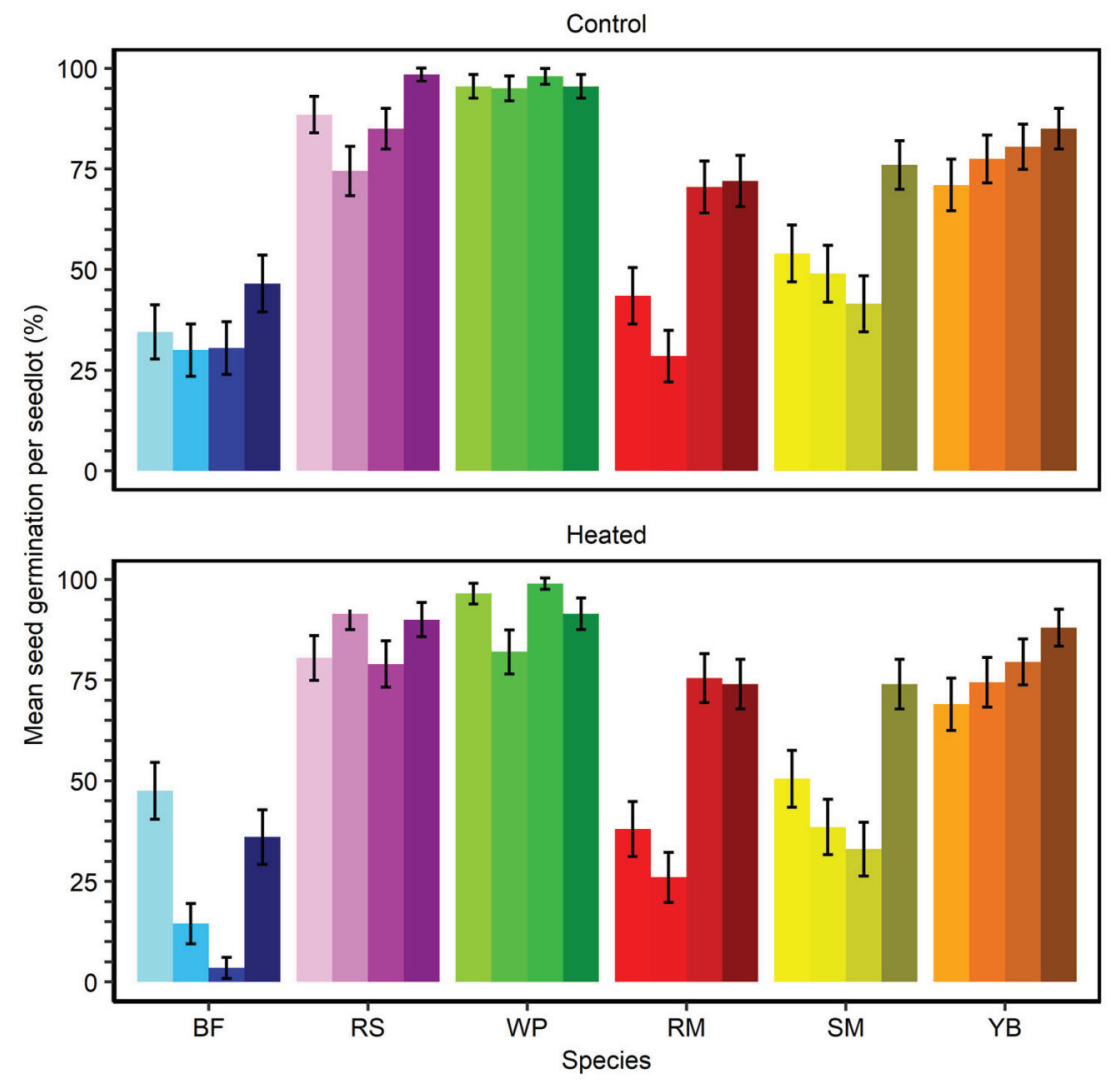

than the average seedbed temperatures that we observed in the heated plots $\left(1.6^{\circ} \mathrm{C}\right)$ of our experiment. Thus, the poor germination success of dormant seeds observed in these studies is not surprising.

While sugar maple germination success appeared to be marginally reduced by the heated treatment, it was not as affected by winter warming as past studies have suggested. Solarik et al. (2016) observed a significant reduction in sugar maple germination success when seeds from Sherbrooke, Québec, Canada, were stratified in a $+5{ }^{\circ} \mathrm{C}$ winter warming treatment carried out in a laboratory setting. Although, the locations of sugar maple seedlots we selected were climatically similar to those from Sherbrooke, our heated treatment did not significantly decrease sugar maple germination success. The disagreement between results may be due to differences in stratification temperatures - the $+5{ }^{\circ} \mathrm{C}$ winter warming treatment that Solarik et al. (2016) applied had a constant incubation temperature of $8.9^{\circ} \mathrm{C}$, while the average seedbed temperature of our heated treatment was only $1.6 \pm 3.3^{\circ} \mathrm{C}$. Considering the optimal temperature for sugar maple seed dormancy release ranges between -1 and $5{ }^{\circ} \mathrm{C}$ (Solarik et al. 2016), a reduction in sugar maple germination success would be expected following stratification at $8.9{ }^{\circ} \mathrm{C}$, while a $1.6{ }^{\circ} \mathrm{C}$ stratification temperature is not likely to have a negative effect. Admittedly, due to the programmed warming limit of $0{ }^{\circ} \mathrm{C}$ between 17 December and 15 March, the temperature difference between the heated and control plots was often less than $+6.0^{\circ} \mathrm{C}$, which may have reduced the likelihood of a warming effect. Nonetheless, because the average ambient air temperature was $-3.4{ }^{\circ} \mathrm{C}$ over the course of the experiment, mean seedbed temperature in the heated treatment was not likely to be frequently outside the optimal stratification temperature range $\left(-1\right.$ to $\left.5{ }^{\circ} \mathrm{C}\right)$ for sugar maple under a $+6{ }^{\circ} \mathrm{C}$ warming scenario. Moreover, with the majority of sugar maple seeds of both treatments having germinated 1-2 weeks prior to the end of the experiment, it is evident that dormancy of sugar maple seeds begins to diminish early in the winter months when the average ambient temperature is at or below $0{ }^{\circ} \mathrm{C}$.

For the deciduous species models, a high conditional $R^{2}$ was produced when the random effect of seedlot was added, suggesting that germination success among seedlots varied substantially; however, the effect of the heated treatment did not elicit a substantial variation in the individual deciduous seedlot response as we observed with balsam fir. In these cases, dissimilarities among deciduous seedlot vigour may have been the leading contributing factor in the observed germination rates. The large variation in balsam fir seedlot response in the heated treatment (relative to the other conifer species) suggests that these seedlots may differ in their sensitivity to warming. Environmental conditions during seed maturation (maternal climate) can influence seed dormancy and germination characteristics (Walck et al. 2011; Penfield and MacGregor 2017). Low temperatures during seed development result in higher levels of seed dormancy, which require longer periods of moist chilling to overcome (Rampart 2019). Some of the balsam fir seedlots that exhibited substantial declines under the heated treatment may have developed under cooler conditions and thus required longer periods of moist chilling to break dormancy. In addition, a high degree of intraspecific variation in seedlot dormancy traits may have increased the range of acceptable climatic conditions for breaking seed dormancy (Bolnick et al. 2011). The impact of these factors, together, may have contributed to the differences in seedlot germination success that we observed in deciduous species in both treatments and the variation in the response to warming exhibited by balsam fir seedlots. 
However, having observed no significant reduction in germination success due to warming at the species level, the different characteristics that seeds of these species may possess will not likely preclude them from persisting under the level of climate warming projected for the Acadian Forest Region over the 21st century.

Admittedly, some of the control germination rates of the tested species (i.e., balsam fir, red maple, and sugar maple) fell below the laboratory germination rates that were observed at the National Tree Seed Centre (Table 1). However, the stratification environment of a field experiment is substantially different from that of a laboratory setting in terms of environmental constancy (Milberg and Andersson 1998), and reduced germination rates of dormant seeds have been observed in past studies that stratified seeds in outdoor environments (Milberg and Andersson 1998; Solarik et al. 2018). In our experiment, the largest differences between the germination rates of laboratory-stratified and fieldstratified seeds were observed with species that produce seeds with intermediate physiological dormancy (i.e., balsam fir, red maple, and sugar maple). This is not surprising as laboratory stratification protocols are specifically designed to optimize dormancy release by providing consistent and ideal temperature, moisture and humidity levels (Bonner and Karrfalt 2008). Therefore, we would expect these two stratification methods to result in different germination rates of seeds with physiological dormancy.

\section{Conclusions}

While snow depth is predicted to decrease with winter warming along with the insulative properties it provides, reductions in soil temperature and the consequential impact on seed germination success may not be as severe as past field studies suggest. Additionally, physiological dormancy of species that require long periods of cold stratification may still be overcome under the shorter winter seasons that are projected for the end of the 21st century in the Acadian Forest Region. Research in the field of seed dormancy and germination has progressed substantially in recent years; however, the genetic mechanisms that signal seeds to remain dormant or initiate germination are not yet fully understood (Nonogaki 2017). Our study showed that under the high-emission, business-as-usual climate change scenario, natural regeneration of balsam fir, red spruce, white pine, red maple, sugar maple, and yellow birch in the Acadian Forest Region may not be impeded by their individual seed characteristics. However, because we did not measure the depth of dormancy in the seedlots of the selected species with intermediate physiological dormancy, it is possible that the seeds we used were not as inhibited by dormancy as we assumed. Also, with the random nature in which seedlot locations were selected, the potential magnitude of variation in seed sensitivity to warming resulting from different environmental conditions during seed development or population genetics could not be measured. With running the experiment for only one winter season, the typical variability in weather patterns may have had a substantial influence on the results. Thus, determining the specific environmental and genetic factors that may influence seed germination success under warmer winters warrants further research.

\section{Author contributions}

WRV, ART, DAM, and LD conceived the ideas and designed methodology; WRV and ART collected the data; WRV and ART analyzed the data; WRV led the writing of the manuscript. All authors contributed critically to the drafts and gave final approval for publication.

\section{Funding}

This study was funded by the Natural Sciences and Engineering Research Council Discovery Grant (No. 239857) and Natural Resources Canada.

\section{Competing interests}

The authors declare that they have no known competing financial interests or personal relationships that could have appeared to influence the work reported in this paper.

\section{Acknowledgements}

We thank Donnie McPhee, Katie Burgess, and John Letourneau for their assistance with seed processing and outdoor plot setup, and Evan Shanks and Shane Heartz for their help with programming and setting up electronics.

\section{References}

Barton, B. 2020. Package 'MuMIn' [online]. Available from https://cran.r-project. org/web/packages/MuMIn/MuMIn.pdf [accessed 25 May 2020].

Baskin, C.C., and Baskin, J.M. 1998. Seeds: ecology, biogeography, and evolution of dormancy and germination. Academic Press, San Diego, Calif., USA.

Baskin, J.M., and Baskin, C.C. 2004. A classification system of seed dormancy. Seed Sci. Res. 14(1): 1-16. doi:10.1079/SSR2003150.

Bates, D., Maecler, M., Bolker, B., Walker, S., Christensen, R., Singmann, H., et al. 2017. Package "lme4" [online]. Available from https://cran.r-project.org/web/ packages/lme4/lme4.pdf [accessed 4 February 2020].

Bolnick, D.I., Amarasekare, P., Araújo, M.S., Bürger, R., Levine, J.M., Novak, M., et al. 2011. Why intraspecific trait variation matters in community ecology. Trends Ecol. Evol. 26(4): 183-192. doi:10.1016/j.tree.2011.01.009. PMID:21367482.

Bonner, F.T., and Karrfalt, R.P. 2008. The woody plant seed manual. Agriculture Handbook 727. USDA Forest Service, Washington, DC, USA.

Bush, E., and Lemmen, D.S. 2019. Canada's changing climate report. Government of Canada. Ottawa, Ont., Canada.

Campbell, J.L., Mitchell, M.J., Groffman, P.M., Christenson, L.M., and Hardy, J.P. 2005. Winter in northeastern North America: a critical period for ecological processes. Front. Ecol. Environ. 3(6): 314-322. doi:10.1890/1540-9295(2005)003 [0314:WINNAA]2.0.CO;2.

Champely, S., 2020. Package 'pwr' [online]. Available from https://cran.r-project. org/web/packages/pwr/pwr.pdf [accessed 30 March 2021].

Decker, K.L.M., Wang, D., Waite, C., and Scherbatskoy, T. 2003. Snow removal and ambient air temperature effects on forest soil temperatures in Northern Vermont. Soil Sci. Soc. Am. J. 67(4): 1234-1242. doi:10.2136/sssaj2003.1234.

Drescher, M., and Thomas, S.C. 2013. Snow cover manipulations alter survival of early life stages of cold-temperate tree species. Oikos, 122(4): 541-554. doi:10.1111/j.1600-0706.2012.20642.x.

Environment Canada. 2019. Canadian climate normals 1981-2010 [online]. Available from https://climate.weather.gc.ca/climate_normals/index_e.html [accessed 27 March 2020].

Fenner, M., and Thompson, K. 2005. The ecology of seeds. Cambridge University Press, Cambridge, UK.

Foster, G., Royer, D., and Lunt, D. 2017. Future climate forcing potentially without precedent in the last 420 million years. Nat. Commun. 8: 14845. doi:10.1038/ncomms14845. PMID:28375201.

Godman, R.M., Yawney, H.W., and Tubbs, C.H. 1990. Sugar maple. In Silvics of North America. Vol. 2: Hardwoods. Edited by R.M. Burns and B.H. Honkala. USDA Forest Service, Washington, DC, USA. pp. 78-91.

Goode, K., and Rey, K., 2019. ggResidpanel: panels and interactive versions of diagnostic plots using 'ggplot2' [online]. Available from https://cran.r-project. org/web/packages/ggResidpanel/index.html [accessed 25 May 2020].

Houle, D., Bouffard, A., Duchesne, L., Logan, T., and Harvey, R. 2012. Projections of future soil temperature and water content for three southern Quebec forested sites. J. Clim. 25(21): 7690-7701. doi:10.1175/JCLI-D-11-00440.1.

Kreyling, J. 2010. Winter climate change: a critical factor for temperate vegetation performance. Ecology, 91(7): 1939-1948. doi:10.1890/09-1160.1. PMID:20715613.

Liu, Y., and El-Kassaby, Y.A. 2015. Timing of seed germination correlated with temperature-based environmental conditions during seed development in conifers. Seed Sci. Res. 25(1): 29-45. doi:10.1017/S0960258514000361.

Luo, X.P., Yuan, Z., Bai, M.J., and Hu, X.W. 2020. Seed dormancy release of Halenia elliptica in response to stratification temperature, duration and soil moisture content. BMC Plant Biol. 20(1): 1. doi:10.1186/s12870-019-2170-7. PMID:31898482.

Mazerolle, M.J., 2020. AICcmodavg: model selection and multimodel inference based on (Q)AIC(c) [online]. Available from https://cran.r-project.org/ web/packages/AICcmodavg/AICcmodavg.pdf [accessed 22 July 2020].

McKenney, D., Pedlar, J., Hutchinson, M., Papadopol, P., Lawrence, K., Campbell, K., et al. 2013. Spatial climate models for Canada's forestry community. For. Chron. 89: 659-663. doi:10.5558/tfc2013-118. 
Mellander, P.-E., Löfvenius, M.O., and Laudon, H. 2007. Climate change impact on snow and soil temperature in boreal scots pine stands. Clim. Change, 85(1-2): 179-193. doi:10.1007/s10584-007-9254-3.

Milbau, A., Graae, B., Shevtsova, A., and Nijs, I. 2009. Effects of a warmer climate on seed germination in the Subarctic. Ann. Bot. 104(2): 287-296. doi:10.1093 aob/mcp117. PMID:19443459.

Milberg, P., and Andersson, L. 1998. Does cold stratification level out differences in seed germinability between populations? Plant Ecol. 134(2): 225-234. doi:10.1023/A:1009793119466.

Mosseler, A., Lynds, J.A., and Major, J.E. 2003. Old-growth forests of the Acadian Forest Region. Environ. Rev. 11(S1): S47-S77. doi:10.1139/a03-015.

Nakagawa, S., and Schielzeth, H. 2013. A general and simple method for obtaining $R^{2}$ from generalized linear mixed-effects models. Methods Ecol. Evol. 4(2): 133-142. doi:10.1111/j.2041-210x.2012.00261.x.

National Tree Seed Centre. 2020. McPhee, D. Natural Resources Canada, Canadian Forest Service - Atlantic Forestry Centre, Impact Note 45E.

Nonogaki, H. 2017. Seed biology updates - highlights and new discoveries in seed dormancy and germination research. Front. Plant Sci. 8: 524. doi:10.3389/fpls.2017.00524. PMID:28443117.

Pachauri, R.K., Meyer, L.A., and the Core Writing Team. 2014. Climate Change 2014: Synthesis Report. IPCC, Geneva, Switzerland.

Penfield, S., and MacGregor, D.R. 2017. Effects of environmental variation during seed production on seed dormancy and germination. J. Exp. Bot. 68(4): 819-825. doi:10.1093/jxb/erw436. PMID:27940467.

Rampart, M. 2019. Seed germination variation among crop years from a Pinus sylvestris clonal seed orchard. Asian J. Agric. Res. 3(1): 1-14. doi:10.13057/ asianjagric/g03101, 10.22158/jar.v3n1p1.

R Core Team. 2020. R: a language and environment for statistical computing [online]. Available from https://www.R-project.org/ [accessed 22 May 2020].

Rowe, J.S. 1972. Forest regions of Canada. Natural Resources Canada, Canadian Forest Service, Ottawa, Ont., Canada.

Seeley, S.D. 1997. Quantification of endodormancy in seeds of woody plants. HortScience, 32(4): 615-617. doi:10.21273/HORTSCI.32.4.615.

Sharratt, B.S., Baker, D.G., Wall, D.B., Skaggs, R.H., and Ruschy, D.L. 1992 Snow depth required for near steady-state soil temperatures. Agric. For. Meteorol. 57(4): 243-251. doi:10.1016/0168-1923(92)90121-J.
Sokal, R., and Rohlf, F. 1995. Biometry: the principles and practice of statistics in biological research. W.H. Freeman, New York, USA

Solarik, K.A., Gravel, D., Ameztegui, A., Bergeron, Y., and Messier, C. 2016. Assessing tree germination resilience to global warming: a manipulative experiment using sugar maple (Acer saccharum). Seed Sci. Res. 26(2): 153-164. doi:10.1017/S0960258516000040.

Solarik, K.A., Messier, C., Ouim, R., Bergeron, Y., and Gravel, D. 2018. Local adaptation of trees at the range margins impacts range shifts in the face of climate change. Global Ecol. Biogeogr. 27(12): 1507-1519. doi:10.1111/ geb.12829.

Sullivan, J. 1993. Picea rubens [online]. In Fire effects information system. USDA, Forest Service, Rocky Mountain Research Station, Fire Sciences Laboratory (Producer), Missoula, Mont., USA. Available from http://www. fs.fed.us/database/feis/plants/tree/picrub/all.html [accessed 3 August 2018].

Taylor, A.R., Endicott, S., and Hennigar, C. 2020. Disentangling mechanisms of early succession following harvest: implications for climate change adaptation in Canada's boreal-temperate forests. For. Ecol. Manage. 461: 117926. doi:10.1016/j.foreco.2020.117926.

Tielborger, K., Petru, M., and Lampei, C. 2012. Bet-hedging germination in annual plants: a sound empirical test of the theoretical foundations. Oikos, 121(11): 1860-1868. doi:10.1111/j.1600-0706.2011.20236.x.

United Nations Environment Programme 2019. Emissions Gap Report 2019. United Nations Environment Programme, Nairobi, Kenya.

van Vuuren, D., Edmonds, J., Kainuma, M., Riahi, K., Thomson, A., Hibbard, K., et al. 2011. The representative concentration pathways: an overview. Clim. Change, 109(1-2): 5-31. doi:10.1007/s10584-011-0148-Z.

Venäläinen, A., Tuomenvirta, H., Heikinheimo, M., Kellomäki, S., Peltola, H., Strandman, H., and Väisänen, H. 2001. Impact of climate change on soil frost under snow cover in a forested landscape. Clim. Res. 17(1): 63-72. doi:10. 3354/cr017063.

Voosen, P. 2019. New climate models forecast a warming surge. Science, 364(6437): 222-223. doi:10.1126/science.364.6437.222. PMID:31000644.

Walck, J.L., Hidayati, S.N., Dixon, K.W., Thompson, K., and Poschlod, P. 2011. Climate change and plant regeneration from seed. Global Change Biol. 17(6): 2145-2161. doi:10.1111/j.1365-2486.2010.02368.x.

Zhang, T. 2005. Influence of the seasonal snow cover on the ground thermal regime: an overview. Rev. Geophys. 43(4): RG4002. doi:10.1029/2004RG000157. 